Res Balticae 7, 2001, pp. 57-65.

\title{
DIPHTONGIZATION AND MONOPHTHONGIZATION IN OLD PRUSSIAN
}

\author{
FREDERIK KORTLANDT \\ Leiden
}

A comparison of the three Old Prussian catechisms yields the following picture (Kortlandt 1998b: 124f.):

(1) ${ }^{*} \overline{\mathrm{e}}>$ I $[\bar{e}]>$ II [ie] $>$ E [ī], e.g.

I turrettwey, II turryetwey, E turritwei.

I stenuns, II styienuns, E stĩnons.

(2) *ēi > I [ēi] $>$ II, E [ieil, e.g.

I palletan, II praliten, E pralieiton.

(3) *ēn > I [ēn] > II, E [ien], e.g.

I penckts, II pyienkts, E piēncts.

(4) ${ }^{*} \bar{i}>$ I, II [ei] $>$ E [i] $]$, e.g.

I preiken, II preyken, E prijki.

I leiginwey, II leygenton, $\mathrm{E}$ līgint.

I geiwans, II geywans, E gijwans.

I geiwin, II geywien, E gijwan.

I polleygo, II poleygo, E polijgu.

I deyg, II deygi, E dijgi.

This close diphthong remains distinct from open ${ }^{*} \mathrm{ei}>$ I, II, E [æi].

(5) $*_{\tilde{a}}>*^{*} \bar{c}>$ I [uo] $>$ II, E [ū], e.g.

I gobuns, II gubons, E gübons.

I pergubuns, II pergubons, E pergūbons.

(6) *ōi > I [uoi] > II [ūi] > E [oui], e.g.

I pugeitty, II puieyti, E poieiti.

I pogeitty, II puietti, cf. E poūis. 
(7) ${ }^{*} \overline{\mathrm{u}}>$ I [ $\left.\overline{\mathrm{u}}\right]>$ II, E [ou], e.g.

I sunun nusun, II sounon nouson, E soūnon noūson.

I numons, II noumans, E noūmans.

The question which now arises is: how must these correspondences be interpreted from a structural point of view? It is clear that the orthography of the catechisms is partly subphonemic and partly inaccurate. We must therefore find a way to retrieve the missing features and to assess the correctness of the spellings.

Elsewhere I have argued that the number of irregularities increases toward the end of the Enchiridion (2000a: 72f. and 2000b: 127). This observation is confirmed by the unexpected instances of diphthongized ei for $\bar{i}$ in the Enchiridion, the majority of which are found in the Trawbüchlein and the Tauffbüchlein which make up the final third of the text. If we look at the nominal forms of the root giw- 'live, life', where diphthongal reflexes of ${ }^{{ }^{i}} \bar{i}$ are more frequent than in other words, we find $11 \times \mathbf{i j}, \mathbf{i}, \mathbf{i}$ and $1 \times$ eij in the first two

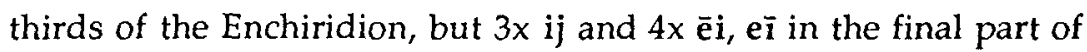
the text, all of these in the Tauffbüchlein and three of the diphthongal forms in the last few pages (Trautmann 1910: 79). I therefore regard eij in vnds steises geijwas 'wasser des lebens' (Trautmann 1910: 41) as the only real exception and consider it a printer's error for monophthongal ij under the influence of the preceding article. This eliminates a third of the diphthongal reflexes of $*_{i}$ in the Enchiridion.

Most other instances can be explained along similar lines. For dìgi 'also' we find $39 x \mathrm{ij}, \overline{\mathbf{i}}, \mathbf{i}$ and $3 x \mathrm{e} \mathbf{i}$, ei in the Enchiridion. The isolated form dei in the Tauffbüchlein is clearly mistaken. The three exceptional forms are probably printer's errors:

(i) Twais Quāits Audāsin kāgi Endangon tijt dēigi nosemien 'Deine Wille geschehe wie im Himmel also auch auff Erden' has kāgi for kāigi, which may have given rise to the mistaken diphthong in dēigi for dīgi. 
(ii) Tou quoitīlaisi mien schan deinan Deigi pokūnst 'Du wöllest mich diesen tag auch behüten' may have ei under the influence of the preceding word deinan.

(iii) Ious Rikijai seggīta stansubban Deigi prīkin tennans $\mathrm{Ir}$ Herrn thut auch dasselbige gegen jnen' has a mistaken imperative ending -ta for -tei (cf. Stang 1966: 418f.) followed by an unexpected inversion. It looks as if -a anticipated the vowel of stan- and was wrongly corrected in the ei of the word which was forgotten and became misplaced. Note that the capital letter in the two instances of Deigi is also peculiar.

In the word malnijks 'child' and its diminutive malnijkiks we find $33 x i j, \bar{i}, i$ and $2 x$ eij, ey in the Enchiridion. While the nom.sg. form malneyks is found on the very last page of the Tauffbüchlein, the acc.pl. form malneijkans is found in the heading Esse Steinans Malneijkans 'Von den Kindern' (Trautmann 1910: 59), where it may have taken its eij for $i j$ from the preceding article. The single instances of debeìkan 'big' and etneīwings 'gracious' have eī for $\mathbf{i}$, $\mathrm{ij}$, which is found $6 x$ and $10 x$ in these words, respectively. The isolated forms ainaweydi 'equally' for ainawīai (ibidem), Rikeis 'Lord' for Rikijs (26x), and poweistins 'things' for powijst- (12x) occur together on a single page of the Trawbüchlein (Trautmann 1910: 65). I have no explanation for the diphthongal reflex in -weidfor-wid- (which is attested dozens of times) in bhe labbai wissaweidin sūndanper schlūsimai 'vnnd wol eitel straff verdienen' (Trautmann 1910: 37), which is probably a mistranslation.

Unlike $e i<{ }^{*} \bar{i}$ and ou $<{ }^{*} \overline{\mathrm{u}}$, we do not find diphthongal reflexes of * ${ }^{*},{ }^{*} \bar{a},{ }^{*} \bar{o}$ in the Enchiridion, except in the case of *ëi, *ēn, * ōi, *ōn (cf. Kortlandt 1988: 89-91). This already suffices to demonstrate the basic reliability of the orthography. Unlike the diphthong $\mathbf{e} i<{ }^{*} \mathbf{i}$, which is regular in the earlier catechisms but has evidently become monophthongized and merged with the reflex of ${ }^{*} \bar{e}$ in the Enchiridion, the diphthong ou $<{ }^{*} \overline{\mathrm{u}}$ is regular in the latter source and distinct from the reflex $\overline{\mathbf{u}}$ of ${ }^{*} \overline{\mathrm{a}}$ and ${ }^{*} \bar{o}$ after labials and velars 
(cf. already de Saussure 1892: 80-83). This is especially clear from the word soūns 'son', which has 18 diphthongal and no monophthongal occurrences, the verb boùt 'to be', which has 30 diphthongal attestations and a single instance of $\mathbf{b} \overline{\mathbf{u}}$ ton, its derivative bousennis 'state', which is found $8 x$ with a diphthong and $2 x$ with bu- (both instances in the Trawbüchlein), and from the pronouns. We find $33 x$ tou , tou, ton (once), tuo (once), tau (once), the latter two instances in the Tauffbüchlein, beside $1 \times$ tū and $24 x$ tu, which was a clitic, and $77 x$ noū-, nou-, nō- (once), naū- (once),

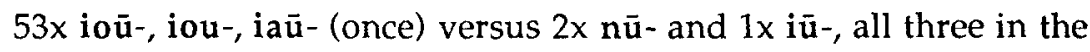
Tauffbüchlein. While the Second catechism is in accordance with the Enchiridion, diphthongization of ${ }^{*} \bar{u}$ in the First catechism is limited to the pronouns $10 x$ thou beside $1 x$ thu (enclitic), $1 x$ yous, $1 x$ noubeside $9 x$ nu- and $2 x$ sun- 'son'. The diphthongization was evidently under way already but lagged behind the development of ${ }^{*} \bar{i}>\mathbf{e}$, which was reversed in the Enchiridion. On the other hand, the diphthongization and monophthongization of ${ }^{*} \bar{e}>$ ie $>\overline{\mathbf{1}}$ seems to have lagged behind the development of ${ }^{*} \bar{o}>$ uo $>\overline{\mathbf{u}}$. Thus, we arrive at the following relative chronology:

$\begin{array}{ll}\text { (D1) } & *_{\bar{i}}>\mathrm{ei},{ }^{*} \overline{\mathrm{o}}>\mathrm{uo}, \\ \text { (D2) } & \overline{\mathbf{u}}>\mathrm{ou}, \overline{\mathrm{e}}>\mathrm{ie}, \\ \text { (M1) } & \mathbf{u} \mathbf{c}>\overline{\mathbf{u}}, \\ \text { (M2) } & \text { ie }>\overline{\mathbf{i}}, \mathrm{e} \mathbf{i}>\overline{\mathbf{i}} .\end{array}$

While the normal reflex of ${ }^{*} \bar{u}$ is ou in the Enchiridion, as has just been pointed out, there are a number of words where we find monophthongal $\overline{\mathbf{u}}$, which suggests a reversal of the diphthongization, as in the case of ${ }^{x_{\bar{i}}}>\mathbf{e i}>\overline{\mathbf{i}}$. Ferdinand de Saussure thought that the diphthongization was blocked by an $i$ in the following syllable (1892: 81), e.g. tūsimtons 'thousand', schlüsitwei 'to serve' (16x, including inflected and derived forms), tūlninai, tūlninaiti 'multiply', as opposed to toūls $(3 x)$, toūlan, but once tūlan 'much', 
prūsiskai (2x), prūsiskan 'Prussian', salūbiskan 'marital' with variants $(4 x)$, salūbin 'spouse' $(2 x)$, sallūbi-, lūbi-, lūbnigs 'priest', lübeniks ( $2 x)$, once sallaūbiskan, but also salūban, sallūban beside salaūban 'marriage', once sallūban for -in 'spouse', sallūbs, sallūbai-, sallubai- beside salaūbai- $(2 x)$ 'marital', salūbsna 'wedding', and finally iūrin 'sea' $(2 x)$, supūni 'lady' $(2 x)$. Though this rule seems to have been universally rejected (e.g. Berneker 1896: 126, Trautmann 1910: 136), I think that it is correct. Trautmann adds the following examples (1910: 137): maldunin 'youth' $(2 x)$, kailūstikun 'health', podrūktinai 'confirm', but drūktai 'firm' with variants $(3 x)$, weldūnai 'heirs' with variants $(3 x)$, rūkai, rūkans 'clothes', dūrai 'shy', krūt 'to fall', kūra 'built', aumūsnan 'washing off', the last three instances in the Trawbüchlein and the Tauffbüchlein. Note that only six of these counter-examples are from the first two thirds of the Enchiridion. A special case is acc.sg. dūsin, dusin, doūsin, daūsin (2x) 'soul', which is most probably an $i / j \bar{a}-$ stem (cf. Kortlandt 1997: 158f.) for which we have to reconstruct an alternating paradigm with nom.sg. ${ }^{*} d \bar{u}$ si and gen.sg. ${ }^{*}$ doūschas, cf. Lith. pati, pačiõs 'wife'.

The question now is: how do these changes fit into the larger picture of the linguistic system? From a structural point of view, the diphthongizations of the long vowels ${ }^{*} \bar{i}>$ ei, ${ }^{*} \bar{u}>$ ou and ${ }^{*} \bar{o}>$ uo, ${ }^{*} \overline{\mathrm{e}}>$ ie do not change the phonemic make-up of the forms, but the monophthongization of $\mathbf{u} \mathbf{c}>\overline{\mathbf{u}}$ and $\mathbf{i e}>\overline{\mathbf{i}}$ implies a phonemic change of $/ \bar{o} />/ \overline{\mathrm{u}} /$ and $/ \overline{\mathrm{e}} />/ \overline{\mathrm{i}} /$. While the latter phoneme merged with earlier $/ \overline{1} /$, which became a monophthong again, earlier $/ \overline{\mathrm{u}} /$ was now rephonemicized as a diphthong /ou/, unless there was an $i$ in the following syllable. I think that this rephonemicization was a consequence of the development of the original four-vowel system /i,e, a, $u /$, which is still attested in the Elbing Vocabulary, into a five-vowel system /i, e, a, o, u/ as a result of the Prussian accent shift (cf. Kortlandt 1988: 90f.). The new rounded back vowel /o/ made the preservation of the distinction between 
ou and $\overline{\mathbf{u}}$ possible but pushed /a/ to the front and thereby caused raising of [æi] /ei/ and [ei] / $1 /$. The asymmetry in the development of the high vowels is thus explained by the rise of the new vowel system. The spelling $æ$ for a in the Second catechism can be viewed as a warning against the retracted pronunciation of the low vowel, which is rarely written o in the catechisms, though o for a was regular after labials and velars in the Elbing Vocabulary (cf. Trautmann 1910: 109).

The Prussian accent shift can be dated before the First catechism, perhaps to the end of the 15th or the beginning of the 16th century. As de Saussure pointed out already (1892: 83fn.), the raising of long vowels was arrested by other developments in final closed syllables. While the endings *-ãs, *a-ai were shortened to -as, -ai before the raising took place, the ending *-ān was raised to *ōn after labials and velars, diphthongized to ${ }^{*}$-uon in the language of the catechisms, and rephonemicized as /-uan/ before further raising yielded new $/ \overline{\mathrm{u}} /$ in the Second catechism and the Enchiridion (cf. Kortlandt 1988: 93f.). This explains the correspondence between the acc.sg. forms of the $\bar{a}$-stems which we find in the three catechisms:

I anterpinsquan, (II enbænden, $E$ enbändan.)

I pattiniskun, II salobisquan, (E sallūban.)

I mergwan, II mergwan, E mērgan.

I krixstianiskun, II krichstianisquan, E crixtiāniskan.

I perroniscon, II perronisquan, E perōniskan.

I prabitscun, II prabusquan, E prābutskan.

The flexion was evidently regularized in the language of the Enchiridion. Final ${ }^{*}-\bar{a}$ and ${ }^{*}-\bar{o}$ yielded $-\overline{\mathbf{u}}$ in widdewũ 'widow', gallū 'head', mergu 'maid', neuter nom.pl. -u in malnijkiku 'little children' (2x), dat.sg. -u < inst.sg. * ${ }^{*}-\bar{b}$ beside -ai < *-āi (cf. Kortlandt 1988: 94), 1st sg. asmu 'am' but $-\mathrm{a}<{ }^{*}-\overline{0}$ in crixtia 'baptize' beside 
regular asmai 'am' < *-o plus *-i (cf. Kortlandt 1979: 56). The

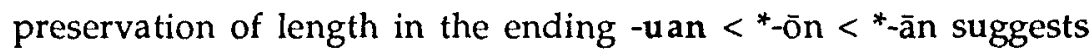
that its final part may have been a centralized nasal vowel, perhaps comparable to the final part of nasal vowels in some varieties of Polish. If this is correct, postvocalic -an stands for a nasalized unrounded central back vowel which may have arisen before the First catechism, and perhaps before the Prussian accent shift already.

The acc.sg. ending is /-ien/ for the $\bar{e}$-stems, /-in/ for the $i$ - and $i / j \bar{a}$-stems, and /-jan/ for the ja-stems (cf. Kortlandt 1997: 158). The position of -ien < *-en, which is written -in in the First catechism and -ien in the Second catechism and the Enchiridion, is wholly analogous to that of -uan, which suggests that postvocalic -en may have been a nasalized unrounded central front vowel which arose before the First catechism already. When *-ēn was rephonemicized as /-ien/, this probably limited the phonetic range of the ending /jan/, where the vowel may have lost the status of an archiphoneme of earlier $/ \mathrm{a} /$ and $/ \mathrm{e} /$. This conjecture is supported by the fact that the acc.sg. form I tawischen, II tauwyschen 'fellow-' is reflected in the Enchiridion as tawischan (4x), tawischen (1x), tawisen (1x).

The remaining question is: why is final ${ }^{*}-\bar{e}$ reflected as $-\overline{\mathbf{e}}$ under the stress, e.g. in semmē 'land', weddē 'led', but as -i after the stress, e.g. in mūti 'mother', pertraūki 'covered'? When the forms semmē and weddē received final stress as a result of the Prussian accent shift, the final vowel had probably become half-long by the shortening of long vowels in final syllables which was in progress at that time. As a consequence, the newly stressed half-long mid vowel did not share the diphthongization to ie but became the front counterpart of $/ \overline{0} /$ in the new five-vowel system. The latter is found as the reflex of earlier /a/ after a labial under secondary lengthening in the preposition pa, e.g. pōstan 'under the', pōmien 'after me' (cf. Kortlandt 1988: 90). It is also found as the reflex of ${ }^{*} \bar{o}$ after $r$ before a nasal in nom.pl. tickrōmai 'just', acc.sg. perōnin 
'common' and their derivatives (24 instances and no counterexamples in the Enchiridion). Final *-ē in mūti and pertraūki was evidently closer to short / $\mathrm{i} /$, with which it merged, than to short /e/, which was a low front vowel [æ] at the time of the Prussian accent shift. The asymmetry between semmēe, weddē on the one hand and gallù 'head', mergu 'maid' on the other is a consequence of the fact that the latter belong to the Balto-Slavic mobile accent type which from the outset already had final stress in the nom.sg. form.

William Schmalstieg has recently (2000) argued that there was a diphthongization of $/ \overline{1} /$ to /ei/ but no monophthongization of /ei/ to $/ \overline{1} /$. I think to have shown that his argument is based on a misunderstanding and that things are much more complicated than he imagines. He also observes that the time span between the catechisms is hardly compatible with major changes in the vowel system. Note that my chronology is based on the more or less archaic character of the texts, not on the printed dates. It is obvious that different dialects can develop at different rates. The Old Prussian proverb Deues does dantes, Deues does geitka 'God give teeth, God give bread' is dated 22 years after the Enchiridion but clearly represents a more archaic variety of the language (cf. Kortlandt 1998a).

\section{References}

Berneker, E. 1896. Die preussische Sprache, Strassburg: Trübner.

Kortlandt, F. 1979. Toward a reconstruction of the Balto-Slavic verbal system, Lingua 49, 51-70.

Kortlandt, F. 1988. Van Wijk's Altpreussische Studien revisited, Studies in Slavic and General Linguistics 12, 89-97.

Kortlandt, F. 1997. Baltic $\bar{e}$ - and $\bar{\imath} / j \bar{a}$-stems, Baltistica 32-2, 157-163. 
Kortlandt, F. 1998a. Two Old Prussian fragments, Baltistik: Aufgaben und Methoden (ed. A. Bammesberger), Heidelberg: Universitätsverlag, 115-119.

Kortlandt, F. 1998b. The language of the Old Prussian catechisms, Res Balticae 4, 117-129.

Kortlandt, F. 2000a. Old Prussian participles, Res Balticae 6, 6975.

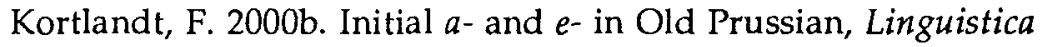
Baltica 8, 125-127.

Saussure, F. de, 1892. Varia, Mémoires de la Société de Linguistique de Paris 7, 73-93.

Schmalstieg, W.R. 2000. Old Prussian: Monophthongizations or diphthongizations?, Linguistica Baltica 8, 143-149.

Stang, C.S. 1966. Vergleichende Grammatik der Baltischen Sprachen, Oslo: Universitetsforlaget.

Trautmann, R. 1910. Die altpreußischen Sprachdenkmäler, Göttingen: Vandenhoeck \& Ruprecht.

Diphtongization and monophthongization in Old Prussian

Frederik Kortlandt, Leiden

Unlike the diphthong ei $<{ }^{*}$, which is regular in the earlier catechisms but has evidently become monophthongized and merged with the reflex of * $\overline{\mathrm{e}}$ in the Enchiridion, the diphthong ou $<{ }^{*} \overline{\mathrm{u}}$ is regular in the latter source and distinct from the reflex $\overrightarrow{\mathbf{u}}$ of ${ }^{*} \bar{a}$ and ${ }^{*} \bar{o}$ after labials and velars. While the normal reflex of ${ }^{*} \overline{\mathbf{u}}$ is ou in the Enchiridion, the diphthongization was blocked by an $i$ in the following syllable. The rephonemicization was a consequence of the development of the original four-vowel system /i, e, a, u/, which is still attested in the Elbing Vocabulary, into a five-vowel system / $i$, e, a, o, $u$ / as a result of the Prussian accent shift. The new rounded back vowel /o/ made the preservation of the distinction between ou and $\overline{\mathbf{u}}$ possible but pushed /a/ to the front and thereby caused raising of [æi] /ei/ and [ei] $/ \bar{i} /$. The asymmetry in the development of the high vowels is thus explained by the rise of the new vowel system. 